\title{
INTRODUCTION: WORLD ROUTES IN THE ARCTIC $^{1}$
}

\author{
Art Leete, Aimar Ventsel
}

The Arctic is associated in popular perception with a vast frozen snow covered empty place. Everybody who has been in the Arctic, whether in the Eurasian or North American part, knows that this stereotype is correct. Indeed, the Arctic is a place with lots of space that determines the lifestyle of the people in this area. All human activities - whether livelihood or mastering of the territory - are and always have been connected with substantial movement. Hunting, fishing, trading, the establishment of settlements and keeping them alive, all this needs the movement of goods and human resources. Economists have calculated that due to the need for transportation of goods and people over huge distances, in combination with the climate, to maintain human activities in the Arctic is more expensive than in other regions of the world (Hill \& Gaddy 2003).

For indigenous people movement has been a necessary part of their lifestyle, they have followed animals, fish and vegetation in order to stock themselves up with meat, furs, firewood and so forth, or to follow trade routes to barter and sell their produce for goods they were unable to find in their own environment. In the case of states, movement into and within the Arctic was and is related to two main reasons: territorial control and resources. For all Arctic states (Russia, USA, Canada, Scandinavian states), the Arctic space was a territory that needed to be controlled and for a long time there has been only one strategy to reach this goal - by establishing settlements, trading posts, military outposts or other permanent or temporary spot on the map with the required human population. Apart from political reasons, appropriating Arctic territories had also an economic aspect. The Arctic is a resource frontier, rich in natural and mineral resources that are difficult to exploit due to the vast distances and hostile climate. This used to be so centuries ago and the situation has not changed much in modern times, as the discussion around exploiting Arctic Ocean oil fields has demonstrated (Cowling 2011). Settlements and 
infrastructure were established over centuries and marked the progress of the mastering of the northern territories. Looking at this process historically, different forms and purposes for movement into and within the Arctic merged very soon. Due to the fact that settlements generally became a centre for social, political and economic life for both the indigenous and incoming population this created infrastructure - whether roads, ships or air traffic - was and is used by all groups of the population, the import of goods has always been in direct dependence on the export of timber, furs, oil, gas, gold and other extracted resources.

The northern icy hemisphere has never been a static place abruptly changing by the emerging colonial powers. As a matter of fact, migration and movement has always existed in Siberia, Scandinavia and the North-American Arctic. Indigenous people moved around, pushed other groups aside, Cossacks, trappers or other early white settlers came and caused different territorial regroupings. It is quite evident that moving is integrated into the northern peoples' culture in a variety of ways. People carry things over long distances. We can find a lot of devices like various sledges, boats or horse and reindeer saddles in their forest and tundra camps that are used for transporting objects if moving on foot using dogs or reindeer sledges.

For a long time, scholarly descriptions have emphasised the nomadic or "wandering" element as the essential one in the life of the northern peoples. Distinguished moving skills have always been a part of the northern peoples' image. During Antiquity and the Middle Ages, extraordinary physical appearance and skills were assigned to demonic strangers who inhabited the northern and eastern edges of the ecumene. For example, a number of Ancient Greek authors described the Sciapods, people with one large foot that enabled them to hop around at enormous speeds (Cohen 1998). These demonic creations were also described by medieval authors who took over the majority of symbols (including the distinctive moving ability and habits of the Sciapods) from Antiquity (Cohen 1998; Ott 1998). A modern intellectual style of portraying the Arctic people's movement was established by the 19th century. The moving component dominated the literary image of northern peoples' until recent times. This "wandering" issue was still imposed as almost mythical or, at least, romantic. The initial ideas about the northern peoples already included an image of extraordinary movement. An image of the northerners as a wandering people was established by early intellectual traditions and observations. This attitude has also been codified in early legislation that was meant to regulate different peoples' rights in the Russian Empire - the 'Statute for Administration of Siberian Indigenes' from 1822, and essentially similar ideas about the Arctic peoples were repeated in the laws of the early Soviet period. 
In the course of the centuries and millennia, moving became firmly established in the academic and popular approach constituting the northern peoples' position in the world.

Somehow a similar attitude can be detected in the early Soviet period. Scholars took this image of the "wandering" inhabitant of the north as axiomatic. At the same time, by now it was treated as a relic of the past which was obstructing progress.

Large-scale exploiting of Northern skirts does not contradict the interests of the indigenous population, if we put all the questions in the right way, taking into account all the peculiarities of indigenous economic life.

It would be absolutely unacceptable to isolate the aborigine from the whole way of life of the country. But it will happen if we allow him to use territories of breathtaking scales in the north, where he will be wandering around within his exotic primitive trap, just as hundreds of years ago. (Dobrova-Yadrintseva 1930)

Siberia in the Western popular image is associated with prison camps and the GULAG while the North American Arctic rather with Jack London's stories of gold diggers. It is less known that Siberia is the most important economic region of modern Russia, in the same way as the North American or Scandinavian Arctic, becoming a resource frontier. However, the exploitation of natural resources was not very active until the industrialization in the 1960s. Although the North American or Scandinavian Arctic was not used - as was the Russian Arctic - as a place for punishment and conviction, in the presecond world war period it had little economic importance either. Later industrialisation, the GULAG or military settlements brought new and different people into the Arctic territories.

The establishment of new settlements and a network of infrastructure has changed not only the lifestyle of the indigenous people but created a unique polar society where different social and ethnic groups live together, tied to each other through mutual interests. The interdependence of these groups is very intensive and has caused an exchange of ideas, concepts and know-how. Unfortunately, the impact of such contact has not always being positive, especially on most of the indigenous societies in the Arctic. The forced sedentarisation and modernisation has often created unwished for consequences for the indigenous people where their lifestyle and social norms had to be adapted to the new environment or restructured radically. All over the Arctic this process meant conflicts between modern and indigenous traditional societies, in many cases ending in the disruption of indigenous cultures (Rasing 1994; Slezkine 1994; Forsyth 1992). Movement and access to means of transport plays an 
important part in these changes. In modern times most indigenous communities face a situation where indigenous women move away to study or work and marry out of their communities. The collapse of the Soviet Union meant a cut in subsidies that directly influenced many settlements in the Russian North. The lack of movement, i.e. decrease of mobility in remote Siberian villages has caused the isolation of indigenous villages, social problems and alcoholism. People who benefitted from cheap subsidised travelling and life in the communities where social security structures were financed by the state, today often face a lack of perspectives and poor living conditions. There are too many negative examples to list them all.

Alongside the physical movement of people, ideas and other intangible objects moved into the North as well. When people and groups reject or adapt to new ideas, it usually directly or indirectly affects their life and is mirrored in their everyday activities. The reorganisation of local life in the Arctic brought new concepts, rearranged family and gender relations, changing traditional life paths. Trading relations have changed local economies since the middle ages where subsistence hunting shifted to commercial hunting for furs (Fisher 1943; Khazanov 1994). Huge changes in movement and territoriality were caused by the states when they began to collect taxes and sedentarise indigenous people. As studies show, the Christian mission has rearranged family and other social relations (Vallikivi 2001; Leete 2004). As a fact, the missions in the Arctic demonstrate in an exemplary way the complexity and social meaning of the religion. In modern times, media like $\mathrm{TV}$, radio, magazines or the Internet has had a huge impact not only in the adoption of new fashions or music but also shaping gender relations (Ventsel 2010; Habeck \& Ventsel 2009).

As we see, life in the Arctic has never been static but full of changes even if the popular notions tend to ignore this. The movement of people, goods and ideas has been crucial for the circumpolar societies and has always been a basis for their existence. The lack of movement usually means isolation and degradation of these societies. Due to factors like climate and distance, human relations in the Arctic are very intense but complex. The concentration of human activities in centres far from each other shows the interrelation of different groups and ideas more clearly than within 'normal' living conditions. Among others, the movement or lack of it demonstrates its impact upon peoples' lives and their practices.

In today's world there exists more and more movement. These movements create new identities and new social relations - missionaries, Chinese migrants, more and more anthropologists move around in Siberia. Siberia seems to be a place where everybody wants to go. How is the movement in Siberia different and where is it similar to movement in other parts of world? The 
Arctic Workshop at the University of Tartu was created to discuss these and similar issues. The first three workshops plan to focus on the issues of movement and its social, cultural, political or economic impact and therefore bear the subtitle "World Routes". In every workshop, we plan to add papers that focus on regions outside of Siberia to initiate discussion between researchers working in different regions of the North and show similarities or differences in movement all over the area.

\section{NOTES}

1 This conference and publication was supported by the European Union through the European Regional Development Fund (Centre of Excellence in Cultural Theory CECT).

\section{REFERENCES}

Cohen, Jeffrey J. 1998. The Order of Monsters: Monster Lore and Medieval Narrative Traditions. In: F. C. Sautman \& D. Conchado \& G. C. Di Scipio (eds.) Telling Tales: Medieval Narratives and the Folk Tradition. New York, pp. 37-38.

Cowling, James 2011. Arctic Oil Exploration: Potential Riches and Problems. BBC News Business 2011 [cited 02.09.20112011].Available from http://www.bbc.co.uk/news/ business-14728856, last accessed on 21 Nov 2011.

Dobrova-Yadrintseva, Lidia N. 1930. Osvoeniie Severnykh Okrain. Sovetskii Sever, No. 5, pp. 17-26.

Fisher, Raymond H. 1943. The Russian Fur Trade 1550-1700. Berkeley Los Angeles: University of California Press.

Forsyth, James 1992. A History of the Peoples of Siberia. Russia's North Asian Colony 1581-1990. Cambridge: Cambridge University Press.

Habeck, Joachim Otto \& Ventsel, Aimar 2009. Consumption and Popular Culture among Youth in Siberia. Zeitschrift für Ethnologie, No. 134, pp. 1-22.

Hill, Fiona \& Gaddy, Clifford 2003. The Siberian Curse. How Communist Planners Left Russia out in Cold. Washington, D.C.: Brookings Institution Press.

Khazanov, Anatoly M. 1994. Nomads and the Outside World. Wisconsin: Wisconsin University Press.

Leete, Art 2004. Invasion of Materialism into the Soviet North: Sedentarisation, Development of Professional Medicine and Hygiene in the 1920-40s. In: E. Kõresaar \& A. Leete (eds.) Everyday Life and Cultural Patterns. International Festschrift for Elle Vunder. Studies in Folk Culture, Vol. 3. Tartu: Tartu University Press, pp. 69-86.

Ott, Norbert H. 1998. Encounters with the Other World: The Medieval Iconography of Alexander the Great and Henry the Lion. In: R. Petzoldt \& P. Neubauer (eds.) Demons: Mediators between This World and the Other. Essays on Demonic Beings from the Middle Ages to the Present. Frankfurt am Main, pp. 75-99. 
Rasing, Wilhelmus C. E. 1994. "Too Many People": Order and Nonconformity in Iglulingmiut Social Process. Nijmegen: Katholieke Universiteit, Faculteit der Rechtsgeleerdheid.

Slezkine, Yuri 1994. Arctic Mirrors. Russia and the Small Peoples of the North. Ithaca and London: Cornell University Press.

Vallikivi, Laur 2001. Adaptation to the Other: Jamb-to Nenets in the 20th Century. Pro Ethnologia, No. 12, pp. 49-62.

Ventsel, Aimar 2010. Hidden Sex and the Ordinary Youth: The Dolgan Way of Maintaining a Good Family Reputation. Anthropology of East Europe Review, Vol. 28, No. 2, pp. 226-241. 